\title{
Pelayanan Fiskus, Pelayanan Perpajakan dan Kepatuhan Wajib Pajak Orang Pribadi di Kabupaten Semarang
}

\author{
Andi Wijayanto ${ }^{1, *}$ \\ ${ }^{1}$ Departemen Administrasi Bisnis, Fakultas Ilmu Sosial dan Ilmu Politik Universitas Diponegoro \\ *Email: andi@undip.ac.id
}

\begin{abstract}
This study was conducted to analyze the performance of the service of tax authorities, Taxation Services and Tax Compliance of taxpayers and the influence tax authorities Services and Taxation Services to the personal taxpayer compliance in Semarang District. The study using a survey research approach. The population in this study were all individual taxpayers in the district of Semarang. Sampling method using judgment sampling with a sample of 100 taxpayers. Methods of data collection using questionnaires, interviews, and documentation. Data analysis using multiple linear regression analysis. The study concluded that: (a) variable of tax authorities service had no significant effect on the variable Taxpayer Compliance; (b) Taxation Services has positive and significant effect on Taxpayer Compliance; (c) variable service of tax authorities and Taxation Services simultaneously have significant effect on Taxpayer Compliance. The research suggestions: (a) taxation socialization should be increased so that all taxpayers know that they have choices and ease to report SPT; (b) Tax Officer must more Proactive and communicative to the taxpayers; (c) rewards and punishments apply to the taxpayer in accordance with the legislation in force; (d) variable service of tax authorities and Taxation Service has simultaneously contributed influences on taxpayer compliance is relatively small at only 16.7 percent. It is therefore recommended for future studies to examine several other factors, such as the understanding of the self-assessment system, education level, income level, tax penalties, or because of attitudes, subjective norms, and perceived behavioral control.
\end{abstract}

Abstraksi Penelitian ini dilakukan dengan tujuan untuk menganalisis kinerja Pelayanan Fiskus, Pelayanan Perpajakan dan Kepatuhan Wajib Pajak serta pengaruh Pelayanan Fiskus dan Pelayanan Perpajakan Wajib Pajak terhadap kepatuhan Wajib Pajak Orang Pribadi di Kabupaten Semarang. Penelitian menggunakan pendekatan survey. Populasi dalam penelitian ini adalah seluruh WP Orang Pribadi (OP) di Kabupaten Semarang. Metode penarikan sampel dilakukan dengan teknik judgement Sampling dengan jumlah sampel 100 WP. Metode pengumpulan data menggunakan Kuesioner, Wawancara, dan Dokumentasi. Analisis menggunakan analisis regresi linier berganda. Penelitian menyimpulkan bahwa: (a) Pelayanan Fiskus tidak berpengaruh signifikan terhadap variabel Kepatuhan WP; (b) Pelayanan Perpajakan berpengaruh positif dan signifikan terhadap variabel Kepatuhan WP; (c) Variabel Pelayanan Fiskus dan Pelayanan Perpajakan secara simultan berpengaruh signifikan terhadap Kepatuhan WP. Saran-saran penelitian: (a) Sosialisasi media penyampaian SPT dan penyuluhan perpajakan harus ditingkatkan agar semua WP mengetahui bahwa mereka memiliki pilihan-pilihan dan kemudahan dalam menyampaikan SPT; (b) Petugas Pajak harus Lebih Proaktif dan Komunikatif kepada para WP; (c) menerapkan reward dan punishment kepada WP sesuai dengan peraturan perundang-undangan yang berlaku; (d) Variabel Pelayanan Fiskus dan Pelayanan Perpajakan secara simultan memiliki kontribusi pengaruh terhadap kepatuhan WP yang terbilang kecil yaitu hanya 16,7 persen. Oleh karena itu bagi penelitian selanjutnya disarankan untuk meneliti beberapa faktor lain, misalnya adalah pemahaman terhadap sistem self assessment, tingkat pendidikan, tingkat penghasilan, sanksi perpajakan, atau karena faktor sikap, norma subyektif, dan kontrol perilaku yang dipersepsikan.

Keywords: Tax authorities Services; Taxation Services; taxpayer compliance

\section{Pendahuluan}

Pajak memegang peranan yang sangat penting dalam pembangunan nasional. Di berbagai negara, pajak merupakan sumber penerimaan negara yang utama selain sumber- sumber penerimaan lainnya. Pajak dapat berfungsi sebagai budgeter, regulerend dan social (Prawisosetoto, et.al dalam Kahono, 2003). Fungsi budgeter berarti pajak berfungsi sebagai penerimaan negara yang digunakan untuk membiayai pengeluaran-pengeluaran 
negara. Berdasarkan fungsi ini maka pajak memiliki kontribusi yang besar bagi APBN dan APBD. Fungsi regulerend berarti pajak merupakan instrumen untuk mengatur berbagai aspek, misalnya mengatur tingkat pertumbuhan ekonomi melalui insentif pajak, atau bahkan sebaliknya untuk menghambat pertumbuhan pelaku dan bidang ekonomi tertentu. Fungsi mengatur ini menurut Mardiasmo (2008) berarti pajak berfungsi sebagai alat untuk mengatur atau melaksanakan kebijakan pemerintah dalam bidang sosial dan ekonomi. Sedangkan fungsi sosial pajak adalah untuk menanggulangi ketimpangan sosial, misalnya penerapan pajak progresif bagi masyarakat dengan memberlakukan tarif pajak yang berbeda untuk tingkat penghasilan yang berbeda.

Mengingat pentingnya sektor pajak dalam pembangunan nasional, maka pemerintah Republik Indonesia dari tahun ke tahun terus berupaya untuk meningkatkan penerimaan negara dari sektor pajak. Salah satu kebijakan penting yang pernah dilakukan dalam bidang perpajakan adalah reformasi perpajakan (tax reform) pada tahun 1983. Berdasarkan reformasi perpajakan tersebut, sistem pemungutan pajak di Indonesia mengalami perubahan dimana mulai saat itu diterapkan self assessment system. Pada sistem ini, WP diberi tanggung jawab dan kepercayaan untuk menghitung, membayar serta melaporkan sendiri pajak terutang kepada negara. Pajak yang disetor oleh WP dianggap benar sampai pemerintah dapat membuktikannya salah (Sultoni, 2013). Reformasi perpajakan berikutnya dilakukan pada tahun 1994 dan 2000 (Kahono, 2003).

Namun penerapan sistem ini bukannya tanpa kelemahan. Kelemahan utama dari sistem ini adalah bahwa pemungutan pajak tidak akan efektif bila WP tidak memiliki kesadaran untuk menghitung, membayar serta melaporkan sendiri pajak terutangnya kepada negara serta kurangnya pengawasan dari aparat pajak. Maka dari itu, isu tentang kepatuhan WP menjadi faktor penting bagi efektifitas peningkatan pendapatan negara dari sektor pajak.

Namun upaya untuk meningkatkan penerimaan negara dari sektor pajak menghadapi beberapa kendala. Salah satu kendala utama yang banyak dihadapi adalah rendahnya tingkat kepatuhan WP untuk membayar pajak. Menurut catatan Ditjen Pajak, pada tahun 2012 baru sekitar 25 juta WP orang pribadi yang sudah membayar pajak dari sekitar 60 juta WP orang pribadi yang seharusnya membayar pajak. Sedangkan untuk WP badan usaha, baru sekitar 520 ribu yang menyerahkan SPT (Surat Pemberitahuan). Jumlah tersebut adalah 10,4 persen dari sekitar 5 juta badan usaha yang seharusnya mampu membayar pajak (Petrus dalam www.jpnn.com).

Di Jawa Tengah sendiri tingkat kepatuhan WP masih tergolong cukup rendah. Direktorat Jenderal Pajak (DJP) Jawa Tengah I pada bulan Maret 2013 melaporkan bahwa tingkat kepatuhan WP di DJP Jawa Tengah I pada tahun 2012 hanya sebesar 60 persen (Sukarno, bisnis-jateng.com, 22 Maret 2013). Bahkan pada periode Januari - Maret 2013 tingkat kepatuhan penyampaian Surat Pemberitahuan (SPT) Tahunan Pajak Penghasilan (PPh) WP orang pribadi maupun badan di wilayah Ditjen Pajak Jateng I baru mencapai $52 \%$ saja, yaitu 412.987 dari 801.695 WP (Sukarno, bisnis-jateng.com, 8 April 2013). Dijelaskan bahwa menurunnya tingkat kepatuhan WP di Jawa Tengah salah satu faktor penyebabnya adalah diakibatkan penambahan jumlah WP pribadi yang cukup signifikan hingga ratusan ribu orang, namun tidak semuanya mengerti mekanisme pelaporan SPT-nya sehingga tingkat kepatuhan turun.

Berbagai upaya dilakukan pemerintah, dalam hal ini Direktorat Jenderal Pajak (DJP), untuk meningkatkan kepatuhan WP. Ditjen Pajak telah melakukan berbagai kebijakan di tahun 2012 untuk mencapai tujuan tersebut, antara lain adalah melaksanakan sensus pajak nasional tahap kedua, registrasi ulang Pengusaha Kena Pajak (PKP), pengembangan teknologi informasi untuk mendukung pelayanan dan memberikan kemudahan kepada WP, harmonisasi peraturan perpajakan, peningkatan jumlah jam (kuantitas) maupun kualitas pelayanan dan Kenaikan Penghasilan Tidak Kena Pajak (PTKP) di tahun 2013 (Petrus dalam 
www.jpnn.com).

Sementara itu tingkat kepatuhan WP di Kabupaten Semarang pada tahun 2011 menurut laporan KPP Salatiga menunjukkan angka yang cukup menggembirakan yaitu sebesar 73,9 persen. Namun pada tahun 2012 menunjukkan penurunan yang cukup tajam. Dari total WP orang pribadi sebanyak 70.943 WP, hingga mendekati batas akhir penyerahan SPT (per 31 Maret) hanya tercatat sebanyak 20.000 WP yang telah menyerahkan SPT tahunan atau hanya sebesar 29 persen (Wijayanto dalam Suara Merdeka, 27 Maret 2012). Capaian ini cukup mengkhawatirkan mengingat pada tahun sebelumnya tingkat kepatuhan WP tergolong cukup baik.

Berdasarkan pemikiran tersebut, maka penelitian ini dilakukan untuk membuktikan pengaruh pelayanan fiskus dan pelayanan perpajakan terhadap tingkat kepatuhan WP Orang Pribadi di Kabupaten Semarang dalam membayar pajak penghasilan Orang Pribadi. Tujuan dari dilaksanaknnya penelitian ini adalah: (a) Untuk menganalisis kinerja Pelayanan Fiskus, Pelayanan Perpajakan dan Kepatuhan WP di Kabupaten Semarang; dan (b) Untuk menganalisis pengaruh Pelayanan Fiskus dan Pelayanan Perpajakan WP secara parsial maupun simultan terhadap kepatuhan WP Orang Pribadi di Kabupaten Semarang.

\section{Kajian Teori}

Setiap negara dapat memungut pajak berdasarkan salah satu sistem dari tiga sistem yang secara umum dikenal (Mardiasmo, 2008), yaitu: (a) Official Assessment System, merupakan sistem pemungutan pajak yang memberi wewenang kepada pemerintah (fiskus) untuk menentukan besarnya pajak yang terutang oleh WP; (b) Self Assessment System, merupakan sistem pemungutan pajak yang memberi wewenang kepada WP untuk menentukan sendiri besarnya pajak terutang; (c) With Holding System, merupakan sistem pemungutan pajak yang memberi wewenang kepada pihak ketiga, bukan fiskus maupun WP, untuk menentukan besarnya pajak terutang WP.

Indonesia menerapkan self assessment system dimana WP diberi tanggung jawab dan kepercayaan untuk menghitung, membayar serta melaporkan sendiri pajak terutang kepada negara. Pajak yang disetor oleh WP dianggap benar sampai pemerintah dapat membuktikannya salah. Sistem ini berlaku sejak dilaksanakannya reformasi perpajakan tahun 1983 yang menyebabkan sistem pemungutan perpajakan di Indonesia mengalami perubahan (Sultoni, 2013).

Kelemahan sistem ini adalah bahwa pemungutan pajak tidak akan efektif bila WP tidak memiliki kesadaran untuk menghitung, membayar serta melaporkan sendiri pajak terutangnya kepada negara serta kurangnya pengawasan dari aparat pajak. Maka dari itu, isu tentang kepatuhan WP menjadi faktor penting bagi efektifitas peningkatan pendapatan negara dari sektor pajak.

Efektifitas pemungutan pajak seringkali menemui hambatan dalam pelaksanaannya. Beberapa hambatan yang seringkali ditemui antara lain adalah sebagai berikut (Mardiasmo, 2008): (a) Perlawanan Pasif, berwujud pada keengganan WP dalam membayar pajak yang dapat disebabkan oleh beberapa faktor, antara lain adalah karena perkembangan intelektual dan moral masyarakat, sistem perpajakan yang sulit dipahami oleh masyarakat, serta sistem pengawasan yang tidak diterapkan dengan baik; (b) Perlawanan Aktif, meliputi semua usaha dan perbuatan yang secara langsung ditujukan kepada fiskus dengan tujuan untuk menghindari pajak. Beberapa bentuk dari perlawanan aktif ini antara lain tax avoidance (usaha meringankan pajak dengan tidak melanggar UU) dan tax evasion (usaha meringankan pajak dengan cara yang melanggar UU).

Berdasarkan penjelasan tersebut, maka kepatuhan WP merupakan isu penting dalam efektifitas pemungutan pajak terutama di Indonesia yang menerapkan self assessment system.

Secara emosional pada umumnya orang tidak ada yang merasa senang membayar pajak sehingga mereka selalu berupaya untuk membayar pajak sekecil mungkin. Bahkan 
terdapat kecenderungan untuk menyelundupkan pajak (tax evasion), yaitu usaha penghindaran pajak secara ilegal sepanjang WP tersebut yakin bahwa akibat perbuatannya tidak akan menyebabkannya dihukum (Yudkin dalam Zain, 2005).

Kepatuhan WP dapat diukur berdasarkan beberapa indikator. Menurut Zain (2005), ukuran kepatuhan memenuhi kewajiban perpajakan dapat diukur dan dibandingkan dengan besar kecilnya penghematan pajak (tax saving), penghindaran pajak (tax avoidance), dan penyelundupan pajak (tax evasion). Halhal tersebut dilakukan untuk meminimalkan beban pajak melalui berbagai cara antara lain adalah Pengecualian, Pengurangan, Insentif Pajak, Penghasilan bukan objek pajak, Penangguhan pengenaan pajak, Pajak ditanggung negara, Kerjasama dengan aparat perpajakan, suap dan pemalsuan.

Sedangkan penelitian Bramasto (2012) dalam penelitiannya yang mengacu pada pendapat Nowak menggunakan beberapa hal berikut untuk mengukur tingkat kepatuhan WP, yaitu: mengisi formulir pajak dengan tepat, menghitung pajak dengan jumlah yang tepat dan membayar pajak tepat pada waktunya. Sedangkan penelitian Jotopurnomo dan Mangoting (2013) menambahkan indikator WP paham atau berusaha memahami peraturan perpajakan untuk mengukur kepatuhan WP. Penelitian Patmawati (2010) menggunakan indikator berikut ini untuk mengukur kepatuhan WP yaitu: Tepat waktu Dalam Penyampaian SPT dan WP Tidak mempunyai Tunggakan Pajak

Terdapat berbagai faktor yang dapat memengaruhi kepatuhan WP dalam membayar pajak. Rustiyaningsih (2011) menyebutkan beberapa faktor tersebut antara lain adalah: (a) Pemahaman terhadap sistem self assessment. Indonesia menerapkan self assessment system dimana WP diberi tanggung jawab dan kepercayaan untuk menghitung, membayar serta melaporkan sendiri pajak terutang kepada negara. Pajak yang disetor oleh WP dianggap benar sampai pemerintah dapat membuktikannya salah. Kelemahan sistem ini adalah bahwa pemungutan pajak tidak akan efektif bila WP tidak memiliki kesadaran untuk menghitung, membayar serta melaporkan sendiri pajak terutangnya kepada negara serta kurangnya pengawasan dari aparat pajak. Maka dari itu, isu tentang kepatuhan WP menjadi faktor penting bagi efektifitas peningkatan pendapatan negara dari sektor pajak.Penelitian Rustiyaningsih (2011) menyimpulkan bahwa pemahaman terhadap sistem self assessment merupakan salah satu dari beberapa faktor yang mempengaruhi kepatuhan WP dalam melaksanakan kewajiban perpajakan ; (b) Kualitas Pelayanan Perpajakan. Kaitan antara kualitas pelayanan perpajakan dapat dijelaskan menurut pandangan Andreoni et.al (dalam www.pajak.go.id) yang diantaranya menyebutkan bahwa kepatuhan pajak dapat dipengaruhi oleh struktur organisasi, tenaga kerja, dan etika. Faktor-faktor ini menekankan pada masalah internal di lingkungan kantor pajak. Apabila struktur organisasinya memungkinkan kantor pajak untuk melayani WP dengan profesional, maka WP akan cenderung mematuhi berbagai aturan. Berry dan Parasuraman mengungkapkan bahwa sebuah pelayanan dikatakan berkualitas jika mampu mengoptimalkan beberapa dimensi sebagai berikut: (1) Bukti langsung (tangibles), meliputi fasilitas fisik, perlengkapan, pegawai, dan sarana komunikasi; (2) Keandalan (reliability), yakni kemampuan memberikan pelayanan yang dijanjikan dengan segera dan memuaskan; (3) Daya tanggap (responsiveness), yaitu keinginan para staf untuk membantu para pelanggan (WP) dan memberikan pelayanan dengan tanggap; (4) Jaminan (assurance), mencakup kemampuan, kesopanan, dan sifat dapat dipercaya yang dimiliki para staf; bebas dari bahaya, risiko, atau keraguan; (5) Empati, meliputi kemudahan dalam melakukan hubungan, komunikasi yang baik, dan memahami kebutuhan para pelanggan-WP (Nasution, 2001). Kualitas pelayanan perpajakan dapat dibentuk melalui pelayanan sistem dan prosedur yang diterapkan oleh kantor pajak sebagai sebuah institusi maupun oleh fiskus sebagai individu. Fiskus diartikan sebagai orang atau badan yang mempunyai tugas untuk memungut pajak atau iuran kepada masyarakat (WP), yang gunanya untuk pengeluaran rutin dan pembangunan nasional, dan untuk menyelenggarakan Pemerintahan. Hak dan kewajiban fiskus antara lain adalah 
Memungut pajak kepada Masyarakat, Membantu WP dalam menghitung utang pajaknya, Memantau para WP secara teratur, Berwenang melakukan pemeriksaan, Berwenang melakukan penyegelan, dan Menjamin kerahasiaan data WP (Kesit, 2009). Terkait dengan pelayanan fiskus sebagaimana diatur dalam Surat Edaran Direktur Jenderal Pajak Nomor: Se-84/PJ/2011 Tentang Pelayanan Prima.Penelitian Jotopurnomo dan Mangoting (2013) menyimpulkan bahwa kualitas pelayanan fiskus merupakan salah satu variabel yang berpengaruh signifikan terhadap kepatuhan WP Orang Pribadi di Surabaya. Penelitian Rustiyaningsih (2011) menyimpulkan bahwa Kualitas Pelayanan merupakan salah satu dari beberapa faktor yang mempengaruhi kepatuhan WP dalam melaksanakan kewajiban perpajakan. Sedangkan hasil penelitian Syafiqurrahman dan Suranta (dalam Rustiyaningsih, 2011) menemukan kesimpulan yang berbeda dimana variabel pelayanan tidak berpengaruh signifikan terhadap kepatuhan WP yang disebabkan dikarenakan kurangnya penyuluhan. Penelitian Kahono (2003) menyimpulkan bahwa Kualitas Pelayanan fiskus berpengaruh signifikan terhadap kepatuhan WP; (c) Tingkat Pendidikan. Sistem perpajakan (penghitungan, pembayaran dan pelaporan) masih dinilai sulit dan membingungkan bagi sebagian besar WP. Masyarakat berpendidikan lebih rendah umumnya menemui kesulitan untuk dapat memahami peraturan perpajakan yang rumit dan terus berubah dari waktu ke waktu. Kesulitan ini pada masyarakat berpendidikan rendah menyebabkan mereka menjadi enggan untuk menghitung, membayar dan membuat surat pemberitahuan (SPT) tahunan pajak. Penelitian Rustiyaningsih (2011) menyimpulkan bahwa Tingkat Pendidikan merupakan salah satu dari beberapa faktor yang mempengaruhi kepatuhan WP dalam melaksanakan kewajiban perpajakan. Sedangkan hasil penelitian Syafiqurrahman dan Suranta (dalam Rustiyaningsih, 2011) menemukan kesimpulan yang berbeda dimana variabel tingkat pendidikan tidak berpengaruh signifikan terhadap kepatuhan WP; (d) Tingkat Penghasilan. Besarnya penghasilan WP akan menentukan besarnya pajak terutang. Tingkat penghasilan WP juga akan menentukan kepatuhan mereka dalam membayar pajak. Pada masyarakat dengan penghasilan yang rendah di Indonesia, kehidupan mereka umumnya masih berkutat pada pemenuhan kebutuhan pokok sehingga kewajiban membayar pajak bahkan banyak yang belum muncul dalam pemikiran mereka.Penelitian Rustiyaningsih (2011) menyimpulkan bahwa tingkat penghasilan merupakan salah satu dari beberapa faktor yang mempengaruhi kepatuhan WP dalam melaksanakan kewajiban perpajakan. Sedangkan hasil penelitian Syafiqurrahman dan Suranta (dalam Rustiyaningsih, 2011) menemukan kesimpulan yang berbeda dimana tingkat penghasilan tidak mempengaruhi kepatuhan WP secara signifikan ; (e) Persepsi WP terhadap Sanksi Perpajakan. Pemberian sanksi perpajakan dimaksudkan untuk meningkatkan kesadaran dan kepatuhan WP dalam membayar pajak. Dalam UU No. 36 Tahun 2008 tentang Perubahan Keempat Atas UU No. 7 Tahun 1983 Tentang Pajak Penghasilan Pasal 9 (k) disebutkan bahwa sanksi perpajakan dapat berupa: (a) sanksi administrasi berupa bunga, denda, dan kenaikan; serta (b) sanksi pidana berupa denda yang berkenaan dengan pelaksanaan perundang-undangan di bidang perpajakan. Penelitian Rustiyaningsih (2011) membuktikan bahwa persepsi WP terhadap sanksi perpajakan menjadi salah satu faktor yang mempengaruhi kepatuhan WP dalam melaksanakan kewajiban perpajakan. Berbeda dengan penelitiannya, hasil penelitian Chotimah (dalam Rustiyaningsih, 2011) mendapatkan hasil yang berbeda, yaitu tidak terdapat pengaruh kesadaran terhadap sanksi perpajakan terhadap kepatuhan WP orang pribadi dalam melaksanakan kewajiban perpajakan pajak penghasilan. Penelitian Kahono (2003) menyimpulkan bahwa sikap WP tentang sanksi denda PBB berpengaruh signifikan terhadap kepatuhan WP.

Sedangkan Wenzel (2002) melakukan penelitian mengenai analisis proses norma dalam kaitannya dengan kepatuhan pajak. Penelitiannya mencoba mengungkap pengaruh etika individual dan norma sosial terhadap tingkat kepatuhan pajak. Kesimpulan penelitiannya adalah sebagai berikut: (a) Etika individual secara kuat berhubungan signifikan terhadap kepatuhan pajak; (b) Norma sosial, yang secara etika diatribusi ke kelompok 
sosial, mempengaruhi kepatuhan pajak hanya pada saat seseorang mengidentifikasi dirinya pada kelompok sehingga sebagai konsekuensinya menginternalisasi norma tersebut sebagai etika mereka sendiri.

Berdasarkan kajian teori dan penelitian terdahulu, maka dirumuskan hipotesis penelitian sebagai berikut:

H1 : Pelayanan Fiskus Pajak berpengaruh terhadap kepatuhan WP Orang Pribadi di Kabupaten Semarang.

H2: Pelayanan Perpajakan WP berpengaruh terhadap kepatuhan WP Orang Pribadi di Kabupaten Semarang.

H3: Pelayanan Fiskus dan Pelayanan Perpajakan WP secara simultan berpengaruh terhadap kepatuhan WP Orang Pribadi di Kab. Semarang.

Rumusan hipotesis tersebut di atas dapat digambarkan dalam bentuk model hipotesis sebagai berikut:

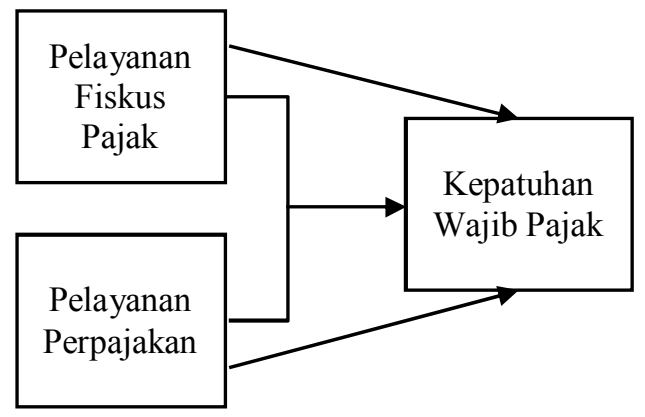

Gambar 1. Model Hipotesis

\section{Metode}

Jenis penelitian ini adalah penelitian eksplanatori yang bermaksud menjelaskan hubungan antar variable penelitian, dalam hal ini adalah Pelayanan Fiskus Pajak, Pelayanan Perpajakan dan Kepatuhan WP. Penelitian dilakukan dengan menggunakan pendekatan penelitian survey dimana pada pendekatan ini data penelitian dikumpulkan dengan menggunakan instrumen utama berupa kuesioner. Populasi dalam penelitian ini adalah seluruh WP orang pribadi yang terdaftar di Kantor Pelayanan Pajak (KPP) Pratama di Kabupaten Semarang. Adapun KPP untuk wilayah Kabupaten Semarang adalah di KPP Pratama Salatiga yang beralamat di Jalan Diponegoro No. 163 Salatiga 50174. Wilayah layanan KPP Pratama Salatiga di Kabupaten Semarang meliputi 17 kecamatan yang terdiri dari 239 desa/kelurahan. Metode penarikan sampel dilakukan dengan teknik judgement Sampling. Kriteria sampel adalah sebagai berikut: (a) Menjadi WP sedikitnya sejak tahun 2011 (minimal sejak dua tahun terakhir penyampaian SPT Tahunan) atau lebih lama; (b) Menyampaikan Surat Pemberitahuan Tahunan (SPT) pajak penghasilan sedikitnya dua kali.Sedangkan ukuran besarnya sampel ditentukan dengan rumus Slovin pada probabilitas 10 persen yaitu sebanyak 100 orang responden. Skala pengukuran menggunakan skala sikap Likert. Metode pengumpulan data yang digunakan dalam penelitian ini adalah Kuesioner, Wawancara, dan Dokumentasi. Analisis data dilakukan dengan Analisis Regresi Linier.

\section{Hasil}

Proporsi terbesar dari distribusi umur responden WP adalah antara 46 hingga 50 tahun sebanyak 25 persen, diikuti oleh umur 36 hingga 40 tahun sebanyak 22 persen, umur antara 31 hingga 35 tahun sebanyak 18 persendanumur antara 41 hingga 45 tahun sebanyak 17 persen. Jadi, dapat dilihat pula bahwa jumlah responden WP pemegang NPWP di Kabupaten semarang terbanyak berdasarkan umur adalah WP yang berumur antara 33 hingga 50 tahun. Ketiga kelompok usia ini dari seluruh responden memiliki proporsi sebesar 79 persen. Usia ini merupakan usia kerja dimana kebanyakan memiliki NPWP secara otomatis karena ketentuan di tempat kerja atau karena kebutuhan NPWP sebagai pendukung usaha. Sedangkan kelompok responden terkecil berada pada rentang umur antara 63 hingga 74 tahun, yaitu hanya terdapat dua WP (2\%) saja.

Responden WP yang disurvei lebih banyak berjenis kelamin laki-laki yaitu sebanyak 69 orang WP atau sebesar 69 persen. Responden WP yang disurvei 
kebanyakan menjalankan pekerjaan sebagai PNS (39 persen), berpendidikan sarjana (S-1) yaitu sebanyak 47 persen. Responden WP yang disurvei mayoritas berasal dari Kelurahan Genuk sebanyak 13 persen, dan dari Kecamatan Ungaran Timur (28 persen), Bancak ( 25 persen), dan Bergas (21 persen) dengan total ketiga kecamatan tersebut sebanyak 74 persen. Berdasarkan tahun kepemilikan NPWP mayoritas telah memiliki NPWP sejak 2010 sebanyak 17 persen.

Fiskus pajak memegang peranan penting dalam memberikan pelayanan karena mereka adalah bagian terdepan dari pelayanan perpajakan yang langsung berinteraksi dengan konsumen. Sedemikian pentingnya peranan petugas pajak dalam memberikan pelayanan sehingga Direktorat Jenderal Pajak Departemen Keuangan RI menetapkan prosedur operasi standar tentang bagaimana petugas pajak harus bersikap terhadap WP. Melalui Surat Edaran Direktur Jenderal Pajak Nomor: Se-84/PJ/2011 diatur mengenai sikap petugas pajak dalam menghadapi WP, antara lain harus dapat bersikap hormat, ramah, dan informatif.

Berikut ini disajikan penilaian responden mengenai pelayanan fiskus dalam bidang perpajakan di Kabupaten Semarang.

Tabel 1. Deskripsi Variabel Pelayanan Fiskus

\begin{tabular}{lllll}
\hline & Mean & Mode & Min & Max \\
\hline X1.1 & 3,6100 & 4,00 & 2,00 & 5,00 \\
X1.2 & 3,8200 & 4,00 & 2,00 & 5,00 \\
X1.3 & 3,6566 & 4,00 & 2,00 & 5,00 \\
X1.4 & 3,8283 & 4,00 & 2,00 & 5,00 \\
X1.5 & 3,6100 & 4,00 & 2,00 & 5,00 \\
X1.6 & 3,5051 & 3,00 & 2,00 & 5,00 \\
X1.7 & 3,1979 & 3,00 & 1,00 & 5,00 \\
X1.8 & 3,4700 & 3,00 & 2,00 & 5,00 \\
X1.9 & 3,4444 & 3,00 & 1,00 & 5,00 \\
X1.10 & 3,7100 & 4,00 & 2,00 & 5,00 \\
X1.11 & 3,5300 & 4,00 & 2,00 & 5,00 \\
X1.12 & 3,6300 & 4,00 & 2,00 & 5,00 \\
X1.13 & 3,4949 & 3,00 & 1,00 & 5,00 \\
\hline Pelayanan & 3,5794 & 3,38 & 2,38 & 4,92 \\
Fiskus & &
\end{tabular}

Sumber: Analisis Data, diolah (2013)
Berdasarkan tabel di atas dapat dilihat bahwa indikator pelayanan fiskus pajak yang mendapat penilaian tertinggi dari konsumen adalah indikator mengenai mengenakan kartu identitas pegawai di dada dan indikator mengenai kerapian penampilan. Sedangkan indikator dengan penilaian yang terendah adalah indikator mengenai kesediaan fiskus untuk menghubungi kembali WP jika layanan tidak dapat diselesaikan pada saat itu juga. Dalam hal ini fiskus pajak masih cukup kesulitan untuk menangani komunikasi yang intensif terhadap sekian banyak WP yang pengurusannya masih belum dapat diselesaikan pada hari yang sama. WP masih dituntut untuk secara aktif mendatangi tempat pelayanan pajak jika urusannya belum selesai. Secara umum, seluruh indikator variabel berkontribusi pada rata-rata skor variabel pelayanan fiskus yang cukup baik yaitu sebesar 3,58.

Berikut ini adalah penilaian responden atas indikator-indikator variabel pelayanan perpajakan di Kabupaten Semarang:

\section{Tabel 2.Deskripsi Variabel Pelayanan Perpajakan}

\begin{tabular}{lllll}
\hline $\begin{array}{c}\text { Indikator \& } \\
\text { Variabel }\end{array}$ & Mean & Mode & Min & Max \\
\hline X2.1 & 3,6500 & 4,00 & 2,00 & 5,00 \\
X2.2 & 3,5300 & 4,00 & 2,00 & 5,00 \\
X2.3 & 3,2500 & 3,00 & 2,00 & 5,00 \\
X2.4 & 3,3800 & 3,00 & 2,00 & 5,00 \\
X2.5 & 3,2700 & 3,00 & 2,00 & 5,00 \\
X2.6 & 3,2500 & 3,00 & 2,00 & 5,00 \\
X2.7 & 3,2200 & 3,00 & 2,00 & 5,00 \\
X2.8 & 3,3737 & 3,00 & 2,00 & 5,00 \\
X2.9 & 3,4500 & 4,00 & 2,00 & 5,00 \\
X2.10 & 3,3469 & 3,00 & 1,00 & 5,00 \\
X2.11 & 3,3030 & 3,00 & 2,00 & 5,00 \\
X2.12 & 3,1200 & 3,00 & 2,00 & 5,00 \\
X2.13 & 3,1500 & 3,00 & 2,00 & 5,00 \\
X2.14 & 3,2700 & 3,00 & 2,00 & 5,00 \\
\hline Pelayanan & 3,3339 & 3,43 & 2,36 & 4,79 \\
Perpajakan & & & &
\end{tabular}

Sumber: Analisis Data, diolah (2013)

Berdasarkan tabel di atas dapat dilihat bahwa indikator pelayanan fiskus pajak yang mendapat penilaian tertinggi dari konsumen adalah indikator mengenai kelengkapan fasilitas pelayanan di kantor pajak dan mengenai perlengkapan yang digunakan 
dalam memberikan pelayanan. Hal ini menunjukkan bahwa dalam bidang pelayanan perpajakan, responden menilai bahwa dari segi peralatan pendukung pelayanan (tools) sudah baik. Sedangkan indikator dengan penilaian yang terendah adalah indikator mengenai kemudahan menghubungi petugas pajak jika dibutuhkan, serta indikator mengenai komunikasi yang baik antara petugas pajak dengan WP. Secara umum, pelayanan perpajakan di Kabupaten Semarang sudah cukup baik dengan rata-rata skor penilaian responden sebesar 3,33.

Berikut ini adalah penilaian responden atas indikator-indikator variabel Kepatuhan WP di Kabupaten Semarang:

Tabel 3. Deskripsi Variabel Kepatuhan WP

\begin{tabular}{lllll}
\hline & Mean & Mode & Min & Max \\
\hline Y1 & 3,2700 & 3,00 & 2,00 & 5,00 \\
Y2 & 3,1515 & 3,00 & 2,00 & 5,00 \\
Y3 & 2,8500 & 3,00 & 1,00 & 5,00 \\
Y4 & 3,8300 & 4,00 & 2,00 & 5,00 \\
Y5 & 3,8700 & 4,00 & 2,00 & 5,00 \\
Y6 & 4,9500 & 5,00 & 3,00 & 5,00 \\
Kepatuhan & 3,6540 & 3,33 & 2,50 & 4,83 \\
WP & & &
\end{tabular}

Sumber: Analisis Data, diolah (2013)

Berdasarkan tabel di atas dapat dilihat bahwa indikator variabel kepatuhan WP yang mendapat penilaian tertinggi dari konsumen adalah indikator Y6 mengenai frekuensi menunggak pajak dengan rata-rata skor 4,95 . Hal ini menunjukkan bahwa hampir seluruh WP tidak memiliki tunggakan pajak. Dari seluruh responden sebanyak 100 orang WP, terindentifikasi hanya terdapat 4 (empat) orang WP yang pernah menunggak pajak. Dari empat orang WP yang pernah memiliki tunggakan pajak, satu diantaranya dalam frekuensi cukup sering sedangkan tiga lainnya dengan frekuensi tunggakan pajak yang jarang. Secara umum tingkat kepatuhan WP adalah baik dengan rata-rata skor sebesar 3.65 .

Indikator dengan penilaian terendah adalah indikator Y3 mengenai kemampuan WP menghitung pajak dengan jumlah yang tepat dengan rata-rata skor 2,85 . Temuan ini menunjukkan bahwa kebanyakan responden belum memahami penghitungan pajak dengan tepat. Kebanyakan masih membutuhkan konsultasi dan panduan dari petugas pajak atau konsultan pajak untuk dapat menghitung pajak dengan benar.

Hasil analisis regresi linier berganda atas variabel penelitian ditunjukkan pada tabel sebagai berikut:

\section{Tabel 4. Hasil Analisis Regresi Linear Berganda}

\begin{tabular}{|c|c|c|c|c|c|}
\hline & \multicolumn{2}{|c|}{$\begin{array}{c}\text { Unstandardize } \\
\mathrm{d}\end{array}$} & $\begin{array}{c}\text { Standar } \\
\text { dized }\end{array}$ & \multirow[t]{2}{*}{$\mathrm{t}$} & \multirow[t]{2}{*}{ Sig. } \\
\hline & B & $\begin{array}{l}\text { Std. } \\
\text { Error }\end{array}$ & Beta & & \\
\hline (Constant) & 2,194 & 0,336 & & 6,528 & 0,000 \\
\hline $\begin{array}{l}\text { Pelayanan } \\
\text { fiskus }\end{array}$ & 0,154 & 0,126 & 0,163 & 1,221 & 0,225 \\
\hline $\begin{array}{l}\text { Pelayanan } \\
\text { perpajakan }\end{array}$ & 0,272 & 0,132 & 0,276 & 2,065 & 0,042 \\
\hline $\mathrm{R}$ & 0,409 & & F Hit & 9,754 & \\
\hline R Square & 0,167 & & Sig. F & 0,000 & \\
\hline
\end{tabular}

Sumber: Analisis Data, diolah (2013)

Koefisien regresi variabel pelayanan fiskus dan pelayanan perpajakan masingmasing bernilai positif yang menunjukkan adanya pengaruh positif kedua variabel bebas terhadap variabel terikat. Hal ini menunjukkan bahwa semakin baik pelayanan fiskus dan pelayanan perpajakan, maka akan semakin tinggi tingkat kepatuhan WP. Namun demikian, kedua variabel bebas tersebut terbukti bukan merupakan faktor utama yang membentuk kepatuhan WP. Kontribusi variabel pelayanan fiskus dan pelayanan perpajakan terhadap kepatuhan WP terbukti hanya sekitar 16,7 persen yang ditunjukkan melalui koefisien determinasi sebesar 0,167. Sedangkan sebesar 83,3 persen dari kepatuhan WP dipengaruhi oleh faktor lainnya. Demikian juga hubungan antara variabel pelayanan fiskus dan pelayanan perpajakan dengan kepatuhan WP meskipun signifikan, namun tidak cukup kuat yaitu sebesar 0,409.

Variabel Pelayanan Fiskus(X1) secara parsial tidak berpengaruh signifikan terhadap variabel Kepatuhan WP. Pengujian dengan menggunakan nilai signifikansi membuktikan kesimpulan yang sama di mana nilai signifikansi $t$ adalah sebesar 0,225 yang 
berarti lebih besar dibandingkan alpha sebesar 0,10 . Sehingga dapat disimpulkan bahwa variabel Pelayanan Fiskus (X1) tidak berpengaruh signifikan terhadap variabel Kepatuhan WP.

Variabel Pelayanan Perpajakan (X2) secara parsial berpengaruh signifikan terhadap variabel Kepatuhan WP. Pengujian dengan menggunakan nilai signifikansi membuktikan kesimpulan yang sama di mana nilai signifikansi $\mathrm{t}$ adalah sebesar 0,042 yang berarti lebih kecil dibandingkan alpha sebesar 0,10 . Sehingga dapat disimpulkan bahwa variabel Pelayanan Perpajakan (X2) berpengaruh signifikan terhadap variabel Kepatuhan WP.

Berdasarkan hasil analisis data dengan menggunakan regresi linear berganda terhadap variabel-variabel bebas yang meliputi Pelayanan Fiskus (X1) dan Pelayanan Perpajakan (X2) terhadap variabel terikat (Kepatuhan WP) diperoleh nilai $\mathrm{F}_{\text {hitung }}$ sebesar 9,754. Nilai $F_{\text {hitung }}$ tersebut lebih besar dibandingkan dengan nilai $F$ tabel sebesar 2,3581 atau berada dalam daerah penolakan Ho. Dengan demikian Ha diterima, sehingga dapat disimpulkan bahwa seluruh variabel bebas yang meliputi Pelayanan Fiskus (X1) dan Pelayanan Perpajakan (X2) secara simultan memiliki pengaruh yang signifikan terhadap variabel terikat (Kepatuhan WP). Pembuktian hipotesis juga dapat dilakukan dengan membandingkan nilai probabilitas $\mathrm{F}$ (sig. F) dengan nilai alpha $(0,10)$. Nilai sig. $F$ dari hasil perhitungan ditemukan sebesar 0,000. Nilai ini berarti lebih kecil dibandingkan nilai alpha $(0,10)$, sehingga dapat disimpulkan bahwa seluruh variabel bebas secara simultan memiliki pengaruh yang signifikan terhadap variabel terikat.

\section{Pembahasan}

Penerimaan pajak sebagai salah satu sumber pembiayaan pembangunan terus digenjot oleh pemerintah. Berbagai kebijakan dilakukan untuk meningkatkan kepatuhan WP dalam membayar pajak dan menyampaikan Surat Pemberitahuan Tahunan (SPT) pajak. Penelitian ini berusaha menemukan bukti adanya pengaruh antara pelayanan fiskus dan pelayanan perpajakan terhadap tingkat kepatuhan WP.

Hasil analisis membuktikan bahwa pelayanan fiskus tidak memiliki pengaruh yang signifikan terhadap kepatuhan WP. Hasil ini cukup mengejutkan karena beberapa penelitian terdahulu membuktikan sebaliknya. Misalnya hasil, penelitian Jatmiko (2006)

Tabel 5. Kritik, Saran Dan Harapan WP Di Kabupaten Semarang

\begin{tabular}{llcc}
\hline No. & Kritik, Saran\& Masukan & Frekuensi & Persentase \\
\hline 1 & Penyesuaian Batas Pemotongan Pajak & 1 & 1,9 \\
2 & Petugas Lebih Ramah & 3 & 5,6 \\
3 & Penyederhanaan Prosedur & 6 & 11,1 \\
4 & Tingkatkan Pelayanan Perpajakan & 13 & 24,1 \\
5 & Perbanyak Kantor Pelayanan Perpajakan & 5 & 9,3 \\
6 & Sosialisasi Pembuatan SPT \& Penyuluhan & 5 & 9,3 \\
& Perpajakan Pen & 5 & 9,3 \\
7 & Petugas Pajak Lebih Proaktif \& Komunikatif & 1 & 1,9 \\
8 & Tingkatkan Pemerataan WP Baru & 1 & 1,9 \\
9 & Tuntaskan permasalahan pajak di perusahaan & 4 & 7,5 \\
& besar & 3 & 5,6 \\
10 & Berantas korupsi dan mafia pajak & 3 & 5,6 \\
11 & Tingkatkan kemampuan petugas pajak & 1 & 1,9 \\
12 & Penggunaan pajak yang tepat & 1 & 1,9 \\
13 & Tingkatkan peralatan pelayanan perpajakan & 2 & 3,7 \\
14 & Tingkatkan responsibilitas & 54 & 100 \\
\hline
\end{tabular}

Sumber: Analisis Data, diolah (2013) 
yang menyimpulkan bahwa pelayanan fiskus secara parsial memiliki pengaruh positif dan signifikan terhadap kepatuhan WP.

Sebaliknya, variabel pelayanan perpajakan terbukti berpengaruh positif dan signifikan terhadap kepatuhan WP. Hal ini berarti bahwa semakin baik pelayanan yang diberikan maka akan semakin tinggi tingkat kepatuhan WP. Temuan terhadap kedua variabel bebas ini menunjukkan bahwa para WP yang diteliti melihat pelayanan perpajakan sebagai hal yang lebih penting. Para WP juga melihat bahwa pelayanan perpajakan di Indonesia masih banyak diwarnai dengan berbagai masalah. Hal ini dibuktikan dengan beberapa kritik, saransaran dan harapan para WP di Kabupaten Semarang yang dirangkum dan disajikan pada Tabel 5.

Dari hasil identifikasi terhadap kritik, saran, masukan atau harapan WP terhadap bidang perpajakan di Kabupaten Semarang menunjukkan bahwa WP lebih menginginkan perbaikan dalam bidang pelayanan perpajakan dibanding pelayanan fiskus. Hal ini didukung oleh skor penilaian responden terhadap pelayanan perpajakan yang rata-ratanya hanya 3,33 atau lebih rendah dibandingkan dengan rata-rata skor variabel pelayanan fiskus sebesar 3,58.

Berdasarkan data, harapan responden paling banyak adalah agar pemerintah (dalam hal ini Direktorat Jenderal Pajak) dapat meningkatkan kualitas pelayanan (24,1 persen). Di sisi lain, sebanyak 11,1 persen WP juga mengharapkan pemerintah dapat menyederhanakan prosedur perpajakan yang mereka nilai masih sulit dan membingungkan. Kantor Pelayanan Perpajakan juga dinilai kurang banyak oleh 9,3 persen WP. Dampak dari hal ini khususnya dirasakan oleh para WP yang menyampaikan SPT tidak dikoordinir oleh tempat mereka bekerja, misalnya para WP yang pekerjaaannya adalah berwirausaha. Lokasi pelayanan juga dirasakan terlalu jauh bagi masyarakat Kabupaten Semarang karena pelayanan perpajakannya berada di KPP Pratama Salatiga. Hal ini kadangkala menimbulkan adanya rasa malas untuk mendatangi tempat pelayanan pajak. Apalagi
KPP Pratama masih menjadi pilihan pertama dalam menyampaikan SPT dan layanan perpajakan lainnya sebagaimana ditunjukkan pada tabel sebagai berikut:

\section{Tabel 6.Tempat Menyampaikan SPT}

\begin{tabular}{llcc}
\hline No. & $\begin{array}{l}\text { Tempat Menyampaikan } \\
\text { SPT }\end{array}$ & $\begin{array}{c}\text { Freku- } \\
\text { ensi }\end{array}$ & $\begin{array}{c}\text { Persen- } \\
\text { tase }\end{array}$ \\
\hline 1 & $\begin{array}{l}\text { Kantor Pelayanan Pajak } \\
\text { (KPP) }\end{array}$ & 75 & 66,4 \\
2 & $\begin{array}{l}\text { Melalui perusahaan jasa } \\
\text { ekspedisi/kurir }\end{array}$ & 8 & 7,1 \\
3 & $\begin{array}{l}\text { Melalui pos dengan bukti } \\
\text { pengiriman }\end{array}$ & 6 & 5,3 \\
4 & Secara elektronik atau e- & 4 & 3,5 \\
& Filling & 1 &, 9 \\
5 & Mobil Pajak & 19 & 16,8 \\
6 & Lainnya & 113 & 100,0 \\
\hline & Total &
\end{tabular}

Sumber: Analisis Data, diolah (2013)

Berdasarkan tabel di atas dapat dilihat bahwa KPP masih menjadi pilihan terbanyak untuk menyampaikan SPT dan layanan perpajakan di Kabupaten Semarang yaitu dimanfaatkan oleh sebanyak 66,4 persen responden. Sedangkan lokasi atau media layanan yang tidak dimanfaatkan sama sekali oleh responden adalah pojok pajak dan drop box yang ada di mall atau pusat perbelanjaan.

Selain itu bagi yang bekerja di sektor formal, mendatangi lokasi KPP kadangkala juga memakan waktu yang cukup lama hingga kesulitan untuk mendapatkan ijin dari tempat bekerja. Sebenarnya Ditjen Pajak telah menyediakan beberapa sarana untuk penyampaian SPT, namun tidak semua WP mengetahui melalui media apa saja SPT dapat disampaikan. Oleh karena itu, sosialisasi media penyampaian SPT dan penyuluhan perpajakan harus ditingkatkan lagi agar semua WP mengetahui bahwa mereka memiliki pilihan-pilihan dan kemudahan dalam menyampaikan SPT (disarankan oleh 9,3 persen responden).

Harapan lainnya adalah petugas Pajak Lebih Proaktif dan Komunikatif kepada para WP (disarankan oleh sebanyak 9,3 persen responden). Keluhan utama yang sering dilontarkan oleh para WP adalah bahwa WP sering kesulitan untuk dapat menghubungi 
petugas pajak. Sebaliknya petugas pajak juga kurang melakukan komunikasi dengan WP yang masih memiliki permasalahan perpajakan. Hal inilah yang menyebabkan beberapa WP kadangkala lupa untuk menyampaikan SPT meskipun jauh hari sebelumnya sudah pernah mendapat surat pemberitahuan dari Kantor Pajak. Hal ini dibuktikan dengan data mengenai beberapa alasan mereka menunggak pajak sebagaimana ditunjukkan pada tabel berikut ini:

Tabel 7. Alasan WP Menunggak Pajak

\begin{tabular}{lcc}
\hline \multicolumn{1}{c}{ Alasan } & $\begin{array}{c}\text { Juml } \\
\text { ah }\end{array}$ & $\begin{array}{c}\text { Persen } \\
\text { tase }\end{array}$ \\
\hline Lupa & 1 & $25 \%$ \\
\hline $\begin{array}{l}\text { Malas membuat \& } \\
\text { menyampaikan SPT }\end{array}$ & 1 & $25 \%$ \\
\hline $\begin{array}{l}\text { Tidak pernah kena sanksi } \\
\begin{array}{l}\text { Dikecualikan dari kewajiban } \\
\text { menyampikan SPT }\end{array}\end{array}$ & 1 & $25 \%$ \\
\hline Total & 1 & $25 \%$ \\
\hline Sumber Anal & 4 & $100 \%$ \\
\hline
\end{tabular}

Sumber: Analisis Data, diolah (2013)

Berdasarkan tabel tersebut di atas dapat dilihat beberapa alasan mengapa para WP pernah menunggak pajak, diantaranya adalah karena lupa, malas membuat \& menyampaikan SPT, Tidak pernah kena sanksi, dan dikecualikan dari kewajiban menyampikan SPT. Lupa menjadi salah satu alasan mengapa WP menunggak pajak. Oleh karena itu, diharapkan oleh WP kepada para petugas pajak untuk bisa lebih proaktif kepada para WP khususnya jika ditengarai permasalahan baik sengaja maupun karena alasan lupa. Responden yang menunggak pajak juga mengemukakan bahwa selama ini mereka tidak pernah kena sanksi meskipun menunggak pajak. Oleh karena itu penting bagi Pitjen Pajak untuk memberi peringatan sanksi kepada WP yang menunggak dan menerapkan sanksi jika memang tunggakan pajak terjadi tanpa alasan yang dibenarkan oleh undang-undang.

Berbagai kasus yang terjadi di bidang perpajakan yang melibatkan petugas pajak juga menjadi perhatian yang besar bagi para WP. Sektor pajak dilihat sebagai sektor yang menjadi sarang korupsi dan mafia perpajakan. Sebanyak 7,5 persen responden mengharapkan kepada pemerintah untuk memberantas korupsi pajak dan adanya mafia pajak. Kondisi ini juga berkaitan dengan persepsi responden terhadap pemanfaatan pajak selama ini yang dianggap banyak penyelewengan. Sebanyak 5,6 persen responden mengharapkan pajak dapat dimanfaatkan dengan tepat dan tidak diselewengkan.

Hasil analisis data juga membuktikan bahwa secara bersama-sama variabel pelayanan fiskus dan pelayanan perpajakan berpengaruh signifikan terhadap kepatuhan WP. Namun demikian, kontribusi kedua variabel bebas tersebut terhadap kepatuhan WP terbilang kecil yaitu hanya 16,7 persen. Sedangkan sebesar 83,3 persen, kepatuhan WP dipengaruhi oleh faktor lain. Beberapa faktor lainnya tersebut misalnya adalah pemahaman terhadap sistem self assessment, tingkat pendidikan, tingkat penghasilan, sanksi perpajakan (Rustiyaningsih, 2011) atau karena faktor sikap, norma subyektif, dan kontrol keperilakuan yang dipersepsikan (Bradley dalam Mustikasari, 2007).

\section{Tabel 8. Alasan Memiliki NPWP}

\begin{tabular}{lll}
\hline Alasan Memiliki NPWP & $\begin{array}{l}\text { Frekue } \\
\text { nsi }\end{array}$ & $\begin{array}{l}\text { Persent } \\
\text { ase }\end{array}$ \\
\hline $\begin{array}{l}\text { Terpaksa karena peraturan } \\
\text { Untuk pendukung } \\
\text { pekerjaan/usaha }\end{array}$ & 29 & 20,28 \\
$\begin{array}{l}\text { Ingin memperoleh fasilitas } \\
\text { bebas fiskal }\end{array}$ & 34 & 23,78 \\
$\begin{array}{l}\text { Sarana dalam administrasi } \\
\text { perpajakan }\end{array}$ & 3 & 2,10 \\
$\begin{array}{l}\text { Menjaga ketertiban } \\
\text { pembayaran pajak } \\
\text { Menghindari sanksi } \\
\text { perpajakan }\end{array}$ & 18 & 12,59 \\
$\begin{array}{l}\text { Menghindari pemotongan } \\
\text { PPh yang tinggi }\end{array}$ & 22 & 15,38 \\
$\begin{array}{l}\text { Mempermudah mendapat } \\
\text { kredit bank }\end{array}$ & 2 & 12,59 \\
$\begin{array}{l}\text { Tanda Identitas WP dalam } \\
\text { perpajakannya }\end{array}$ & 13 & 9,09 \\
\hline Total & 4 & 2,80 \\
\hline
\end{tabular}

Sumber: Analisis Data, diolah (2013)

Rendahnya kontribusi variabel pelayanan fiskus dan pelayanan perpajakan dalam penelitian ini juga disebabkan karena 
kepatuhan WP dalam membayar pajak dan menyampaikan SPT semata-mata bukan karena kesadaran yang tinggi untuk membayar pajak atau pelayanan perpajakan dan fiskus yang sudah baik, namun juga karena beberapa alasan lainnya. Sebagai contoh, beberapa alasan responden memiliki NPWP ditunjukkan pada Tabel 8 .

Dari berbagai alasan WP memiliki NPWP, beberapa alasan terbanyak diantaranya adalah untuk mendukung pekerjaan atau usaha $(23,78$ persen), terpaksa karena peraturan (20,8 persen), dan menghindari sanksi perpajakan $(12,59$ persen). Proporsi ketiga alasan ini adalah sebesar 56,64 persen. Artinya lebih dari separuh WP memandang kewajiban di bidang perpajakan adalah sebagai beban. WP memiliki NPWP bukan karena kesadaran sebagai warga negara untuk memberikan kontribusi dalam pembangunan, melainkan karena paksaan peraturan dan adanya sanksi yang menyertainya. Dalam hal ini faktor sanksi perpajakan sebagaimana yang dikemukakan Rustiyaningsih (2011) memainkan peranan yang kuat dalam meningkatkan kepatuhan WP.

Demikian pula jika dilihat alasan-alasan WP yang berusaha menyampaikan SPT tepat pada waktunya sebagian besar adalah karena adanya peraturan dan sanksi perpajakan sebagaimana ditunjukkan pada tabel berikut ini:

Tabel 9. Alasan Menyampaikan SPT Tepat Waktu

\begin{tabular}{lll}
\hline Alasan Spt Tepat Waktu & $\begin{array}{l}\text { Frekue } \\
\text { nsi }\end{array}$ & $\begin{array}{l}\text { Persent } \\
\text { ase }\end{array}$ \\
\hline $\begin{array}{l}\text { Menghindari sanksi } \\
\text { perpajakan }\end{array}$ & 43 & 38,05 \\
$\begin{array}{l}\text { Berusaha mematuhi peraturan } \\
\text { Supaya tidak lupa di }\end{array}$ & 45 & 39,82 \\
$\begin{array}{l}\text { kemudian hari } \\
\text { Mendukung tertib }\end{array}$ & 8 & 7,08 \\
administrasi perpajakan & 16 & 14,16 \\
Alasan lainnya & 1 & 0,88 \\
\hline Total & 113 & 100 \\
\hline
\end{tabular}

Sumber: Analisis Data, diolah (2013)

Berdasarkan tabel tersebut di atas dapat dilihat bahwa para WP yang menyampaikan SPT tepat waktupun juga menggunakan adanya peraturan dan sanksi sebagai alasan. Sebanyak 39,82 persen WP yang menyampaikan SPT tepat waktu beralasan karena berusaha mematuhi peraturan, sedangkan sebanyak 38,05 persen WP yang menyampaikan SPT tepat waktu beralasan untuk menghindari sanksi perpajakan. Jika pada sisi lain alasan menunggak pajak adalah karena selama ini mereka tidak pernah kena sanksi, maka penting kiranya bagi pemerintah untuk menerapkan reward dan punishment kepada WP sesuai dengan peraturan perundang-undangan.

\section{Kesimpulan dan Saran}

Berdasarkan pada hasil penelitian, maka dapat ditarik beberapa kesimpulan sebagai berikut: (a) Pelayanan Fiskus secara parsial tidak berpengaruh signifikan terhadap Kepatuhan WP. Pajib pajak melihat pelayanan perpajakan sebagai hal yang lebih penting untuk diperbaiki. Adanya peraturan dan sanksi perpajakan lebih menonjol perannya dalam mendorong WP untuk mematuhi kewajiban perpajakan; (b) Pelayanan Perpajakan secara parsial berpengaruh positif dan signifikan terhadap variabel Kepatuhan WP; (c) Pelayanan Fiskus dan Pelayanan Perpajakan secara simultan berpengaruh signifikan terhadap Kepatuhan WP. Kontribusi kedua variabel bebas tersebut terhadap kepatuhan WP terbilang kecil yaitu hanya 16,7 persen. Sedangkan sebesar 83,3 persen, kepatuhan WP dipengaruhi oleh faktor lain, misalnya adalah pemahaman terhadap sistem self assessment, tingkat pendidikan, tingkat penghasilan, sanksi perpajakan, atau karena faktor sikap, norma subyektif, dan kontrol keperilakuan yang dipersepsikan.

Berdasarkan pada kesimpulan, maka dapat diajukan saran-saran sebagai berikut: (a) Sosialisasi media penyampaian SPT dan penyuluhan perpajakan harus ditingkatkan lagi agar semua WP mengetahui bahwa mereka memiliki pilihan-pilihan dan kemudahan dalam menyampaikan SPT; (b) Petugas Pajak harus Lebih Proaktif dan Komunikatif kepada para WP. Keluhan utama yang sering dilontarkan oleh para WP adalah 
bahwa WP sering kesulitan untuk dapat menghubungi petugas pajak. Sebaliknya petugas pajak juga kurang melakukan komunikasi dengan WP yang masih memiliki permasalahan perpajakan. Hal inilah yang menyebabkan beberapa WP kadangkala lupa untuk menyampaikan SPT meskipun jauh hari sebelumnya sudah pernah mendapat surat pemberitahuan dari Kantor Pajak; (c) Para WP baik yang menyampaikan SPT tepat waktu maupun yang menunggak pajak atau tidak menyampaikan SPT menggunakan adanya peraturan dan sanksi sebagai alasan. Oleh karena itu penting kiranya bagi pemerintah untuk menerapkan reward dan punishment kepada WP sesuai dengan peraturan perundang-undangan yang berlaku; (d) Pelayanan Fiskus dan Pelayanan Perpajakan secara simultan memiliki kontribusi pengaruh terhadap kepatuhan WP yang terbilang kecil. Oleh karena itu bagi penelitian selanjutnya disarankan untuk meneliti beberapa faktor lain, misalnya adalah pemahaman terhadap sistem self assessment, tingkat pendidikan, tingkat penghasilan, sanksi perpajakan, atau karena faktor sikap, norma subyektif, dan kontrol keperilakuan yang dipersepsikan.

\section{Daftar Referensi}

Bramasto, Ari. 2012. Pengaruh Kepatuhan WP Dan Kualitas Informasi Akuntansi Keuangan Terhadap Efektivitas Sistem Self Assessment. Majalah Ilmiah UNIKOM Vol. 10, No. 2, Juli 2012.

Jatmiko, Agus Nugroho. 2006. Pengaruh Sikap WP Pada Pelaksanaan Sanksi Denda, Pelayanan Fiskus Dan Kesadaran Perpajakan Terhadap Kepatuhan Wajib Pajak (Studi Empiris Terhadap Wajib Pajak Orang Pribadi di Kota Semarang). Semarang: Undip.

Jotopurnomo, Cindy \& Yenni Mangoting. 2013. Pengaruh Kesadaran Wajib Pajak, Kualitas Pelayanan Fiskus, Sanksi Perpajakan, Lingkungan Wajib Pajak Berada terhadap Kepatuhan Wajib Pajak Orang Pribadi di Surabaya. Tax \& Accounting Review, Vol.1, No.1, 2013.

Kahono, Sulud. 2003. Pengaruh Sikap Wajib
Pajak Terhadap Kepatuhan Wajib Pajak Dalam Pembayaran Pajak Bumi dan Bangunan (Studi Empiris di Wilayah KP. $P B B$ Semarang). Tesis. Semarang: Universitas Diponegoro.

Kesit, Bambang. 2009. Hukum Pajak. Yogyakarta: Program Studi Akuntansi FE UII.

Mardiasmo. 2008. Perpajakan. Edisi Revisi 2008. Yogyakarta: Penerbit Andi.

Mustikasari, Elia. 2007. Kajian empiris tentang kepatuhan wajib pajak badan di Perusahaan industri pengolahan di surabaya. Simposium nasional Akuntansi X. Makassar: Unhas.

Nasution, M.N. 2001. Total Quality Management. Jakarta: Ghalia Indonesia.

Patmawati, Yulia. 2009. Pengaruh Kualitas Pelayanan Pajak Terhadap Kepatuhan Wajib Pajak Penghasilan Orang Pribadi Pada Kantor Pelayanan Pajak Pratama Bandung Cibeunying. http://elib.unikom.ac.id/,Unikom Digital Library. Diunduh pada 7 Mei 2013.

Petrus, Kismantoro. 2012. Tingkat Kepatuhan Wajib Pajak Masih Rendah.http://www.jpnn.com/index.php?

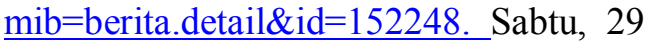
Desember 2012.

Rustiyaningsih, Sri. 2011. Faktor-faktor yang Mempengaruhi Kepatuhan Wajib Pajak. Widya Warta, Nomor 02, Tahun XXXV, Juli 2011.

Sukarno, Puput Ady. 2013. WAJIB PAJAK: 150 Orang Pembayar Pajak Tertinggi Dapat Penghargaan.http://www.bisnisjateng.com/, 22 Maret 2013.

Sukarno, Puput Ady. 2013. WAJIB PAJAK: DJP Jateng I Gencarkan Tingkat Kepatuhan Wajib Pajak.http://www.bisnis-jateng.com/, 25 Maret 2013.

Sukarno, Puput Ady. 2013. PAJAK JATENG: 
Tingkat Kepatuhan Penyampaian SPT Hanya $\quad 52 \%$. http://www.bisnisjateng.com/, 8 April 2013.

Sultoni. 2013. PMK 16/PMK.03/2013 Makin Meneguhkan DJP. http://www.pajak.go.id/. Diunduh pada 7 Mei 2013.

Wenzel, Michael. 2002. An Analysis Of Norm Processes In Tax Compliance. $A N U$ Working Paper No 33, July 2002. Canberra: Centre for Tax System Integrity, Research School of Social Sciences, Australian National University.

Wijayanto, Wahyu. 2012. Baru 20.000 WPOP
Melaporkan SPT.Suara Merdeka, 27 Maret 2012.

Zain, Mohammad. 2005. Manajemen Perpajakan. Jakarta: Penerbit Salemba Empat.

2008. Undang-Undang Republik Indonesia Nomor 36 Tahun 2008 dan penjelasannya Tentang Perubahan Keempat Atas Undang-Undang Nomor 7 Tahun 1983 Tentang Pajak Penghasilan.

. 2011. Surat Edaran Direktur Jenderal Pajak Nomor: SE - 84/PJ/2011 Tentang Pelayanan Prima. 